Blažka Müller Pograjc*

Jasmina Markič ${ }^{* *}$

University of Ljubljana
UDK 811.134.3'342.41(4):81'355

DOI: 10.4312/linguistica.57.1.243-254

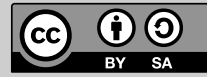

\title{
NASAL VOWELS AND DIPHTHONGS IN EUROPEAN PORTUGUESE: A PROBLEM FOR SLOVENE SPEAKERS
}

\section{INTRODUCTION}

This paper deals with a specific situation of Slovene students of Portuguese as a foreign language (L2). Such students need a relatively large amount of training to master the sounds that have no near equivalent in Slovene. They thus need much more practice than some other groups to master Portuguese pronunciation, and particularly that of European Portuguese, in order to reach an acceptable level. In trying to identify the problem areas of Portuguese pronunciation training, the teacher must examine the interaction between the mother tongue and foreign language in question. In this context, contrastive analysis can have an important role in students' awareness of their pronunciation errors and in improving their production of L2 sounds.

The first part of the paper describes, from a contrastive point of view, the main features of the sound systems of European Portuguese (L2) and Slovene (L1) - in particular with regard to place and manner of articulation - and focuses on the pronunciation of nasal vowels and diphthongs in European Portuguese as one of the difficulties that Slovene learners have to confront. Some common errors resulting from the systemic differences between Slovene and European Portuguese are also explained.

The second part of the paper presents a pilot study that focuses on the production of nasal vowels. The key aim of this study is to answer the decisive question as to whether the cause of the pronunciation problems that Slovene learners of European Portuguese have with these sounds is merely the absence of nasal vowels in the Slovene phonetic system, or if other factors are involved as well.

\section{THE VOWEL SYSTEMS OF STANDARD SLOVENE AND EUROPEAN PORTUGUESE}

\subsection{Slovene}

The Slovene vowel system consists of eight phonemes /i, e, $\varepsilon$, , a, a, o, u/, as shown in the chart and examples below. All vowels occur in both stressed and unstressed positions, but /e/ and /o/ occur in unstressed positions in only a few grammatical words (Šuštaršič/ Komar/Petek 1999: 137; see also Toporišič 1984). The length is not considered a distinctive feature, as long vowels occur in stressed and short vowels in unstressed positions.

* blazka.mullerpograjc@ff.uni-lj.si

** jasmina.markic@ff.uni-lj.si 


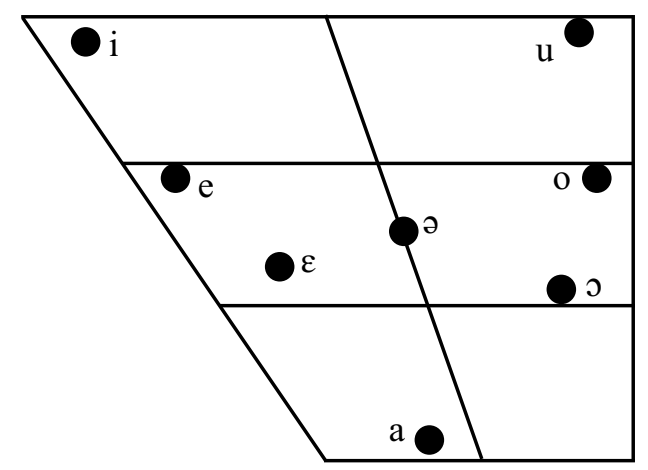

Figure 1: Slovene vowel system (Šuštaršič/Komar/Petek 1999: 137)

Table 1: Examples of the Slovene vowel system (Šuštaršič/Komar/Petek: 137):

\begin{tabular}{|c|c|c|c|c|c|c|c|}
\hline \multicolumn{4}{|c|}{ Stressed } & \multicolumn{4}{|c|}{ Unstressed } \\
\hline i: & mi:t & mit & myth & $\mathrm{i}$ & 'mi:ti & miti & myths \\
\hline $\mathrm{e}:$ & me:t & med & honey & $\mathrm{e}$ & ze've: & $\check{z} e v e$ & already knows \\
\hline$\varepsilon:$ & pe:ta & peta & heel & $\varepsilon$ & 'pe:te & pete & heel (gen) \\
\hline $\mathrm{a}:$ & ma:t & mat & checkmate & $\mathrm{a}$ & ma:ta & mata & checkmate (gen) \\
\hline o: & 'po:ten & poten & sweaty & 0 & po'te:m & potem & then \\
\hline $\mathrm{o}:$ & po:t & pot & path & o & bo'flo & bo šlo & will go \\
\hline $\mathrm{u}:$ & pu:st & pust & carnival & $\mathrm{u}$ & 'pu:stu & pustu & carnival (dat) \\
\hline ว: & pə:s & pes & $\operatorname{dog}$ & $\partial$ & do:bar & dober & good \\
\hline
\end{tabular}

Phonetic diphthongs in Slovene occur when "the approximants $/ \mathrm{v} /$ and $/ \mathrm{j} /$ are preceded by a vowel and followed by a consonant or a word boundary. The labiodental /v/ in these positions becomes a rounded second element of a diphthong, i.e. $[\mathrm{u}]$, and /j/ becomes [i]" (Šuštaršič/Komar/Petek 1999: 137).

Table 2: The diphthongs in Slovene

\begin{tabular}{|l|l|ll|}
\hline ei & glei & glej & look (imp) \\
\hline ai & dai & daj & give (imp) \\
\hline oi & tvoi & tvoj & your (masc sg) \\
\hline oi & boi & boj & battle \\
\hline ui & tui & tuj & foreign \\
\hline iu & piu & pil & drank \\
\hline eu & peu & pel & sang \\
\hline cu & leu & lev & lion \\
\hline au & pau & pav & peacock \\
\hline ou & pou & pol & half \\
\hline ou & to:pou & topel & warm \\
\hline
\end{tabular}

(Šuštaršič/Komar/Petek 1999: 137) 


\subsection{Portuguese}

Portuguese has one of the richest vowel phonologies of all Romance languages, having both oral and nasal vowels, diphthongs, and triphthongs. The analysis of Portuguese vowels is fundamentally related to the position of the accent: tonic, pretonic, postonic or final. Nasal vowels are presented in smaller numbers than the oral ones, and do not occur in postonic syllables, except in some diphthongs. ${ }^{1}$

\subsubsection{Monophthongs}

European Portuguese has fourteen monophthongs, nine oral and five nasal ones. Slovene speakers have no difficulties in distinguishing and pronouncing open and closed oral vowels, but they should pay attention to distinguishing / $/ \mathrm{e} /$ and $/ \mathrm{w} /$, which occur in unstressed positions in Portuguese. In Slovene there is a similar sound $/ \partial /$, but it does not correspond exactly to any of these two European Portuguese sounds. The vowel /w/ "occurs only in unstressed syllables and is often represented by /a/ but does not correspond to the mid-central quality associated with schwa. It is a fronted and lowered high back unrounded vowel" (Cruz-Ferreira 1999: 127). Slovene students have to learn the pronunciation of nasal vowels, as there are no equivalents in Slovene and they tend to pronounce them as oral vowels. ${ }^{2}$ In contrast, the diphthongs and hiatus vowels in Portuguese very rarely cause difficulties in the pronunciation of Slovene learners, as there are diphthongs in Slovene, as well as such combinations as joj and jej, similar to Portuguese triphtongs.

Azevedo (1981) considers three distributions of nasal vowels in Portuguese. The first is the nasalisation of elements adjacent to a nasal consonant of the next syllable. The author's opinion is that the degree of the nasalisation varies according to the speaker, but the tendency is to nasalize the accented syllable nucleus, as in doma ['dõmə] (Azevedo 1981: 23). The second type of nasalisation are vowels followed by nasal consonants in the final position of the syllable adjacent to non-nasal consonants in the next syllable. Orthographically these are represented as vowel + nasal consonant (e.g. campo, canto; ['kãmpu], ['kãntu]). The third case of nasalisation has to do with the nucleus of the nasalized syllable in the final position. It is interpreted as the second type mentioned above, i.e. as a sequence of a simple or compound nucleus followed by a nasal consonant (mãe, mão, põe, fim, tem, som) (Azevedo 1981: 26). It is noted that the obstruction of the final nasal consonant is present in all the cases even if the sound is a palatal one followed by a closed vowel / $\mathrm{i} /$ or $/ \mathrm{u} /$ or a velar consonant preceded by an open or half open vowel (/a/, /e/, /o/).

The author (ibid.) considers the nucleus of a half open front vowel /e/ a factor causing difficulties in the pronunciation of nasals by foreigners. A sequence/en/ in the final

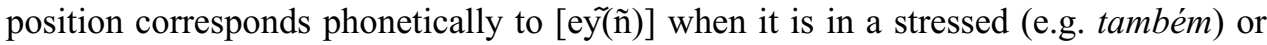
unstressed position (e.g. sem abrigo). The insertion of an [i] between e and the next

1 For more information on Portuguese phonology and grammar, see Cunha and Cintra (1984), Espada (2017), Mateus, Falé and Feitas (2005), and Mateus et al. (2006).

$2 C f$. Markič (2008). 
nasal sound creates a glide and emphasizes the nasalisation of the sequence of segments. For this reason, the comprehension and production of nasals by foreigners can be hampered.

Table 3: Examples of European Portuguese vowels (Cruz-Ferreira 1999: 127)³

\begin{tabular}{|c|c|c|c|c|c|c|c|}
\hline \multicolumn{4}{|c|}{ Oral vowels } & \multicolumn{4}{|c|}{ Nasal vowels $^{2}$} \\
\hline $\mathrm{i}$ & vi & $v i$ & saw $(1 \mathrm{sg})$ & $\tilde{1}$ & vĩm & vim & came $(1 \mathrm{sg})$ \\
\hline $\mathrm{e}$ & ve & $v \hat{e}$ & see $(3 \mathrm{sg})$ & $\tilde{\mathrm{e}}$ & 'ẽtru & entro & enter (1 sg) \\
\hline$\varepsilon$ & $\mathrm{s} \varepsilon$ & $s e ́$ & cathedral & $\tilde{\mathrm{e}}$ & '̃̂tru & antro & den \\
\hline $\mathrm{a}$ & va & $v a ́$ & go $(3 \mathrm{sg})$ & $\tilde{0}$ & sõ & som & sound \\
\hline 0 & so & só & alone & $\tilde{\mathrm{u}}$ & 'mũdu & mundo & world \\
\hline 0 & so & sou & I am & & & & \\
\hline $\mathrm{u}$ & 'mudu & mudo & mute & & & & \\
\hline$e$ & pe'gar & pagar & to pay & & & & \\
\hline u & puígar & pegar & to grip & & & & \\
\hline
\end{tabular}

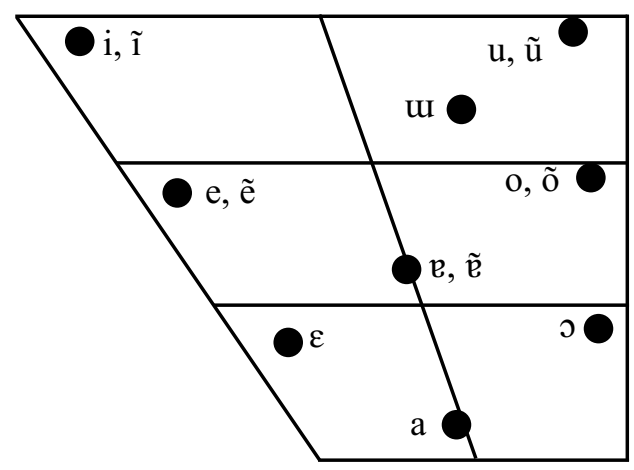

Figure 2: Portuguese vowel system (Cruz-Ferreira 1999: 127)

\subsubsection{Diphthongs and Triphthongs}

Portuguese is very rich in diphthongs, and in the European variety there are fourteen of these, ten oral and four nasal ones, as shown below.

Table 4: Portuguese diphthongs and triphthongs

\begin{tabular}{|l|l|ll|}
\hline$\varepsilon \mathrm{i}$ & e'nci & anéis & rings \\
\hline ai & sai & sai & go out $(3 \mathrm{sg})$ \\
\hline zi & sei & sei & know $(1 \mathrm{sg})$ \\
\hline oi & moi & mói & grind $(3 \mathrm{sg})$ \\
\hline oi & 'moite & moita & thicket \\
\hline
\end{tabular}

3 The author uses the term nasalized vowels. See also Rothe-Neves (2012). 


\begin{tabular}{|c|c|c|c|}
\hline ui & e'nuif & anuis & agree $(2 \mathrm{sg})$ \\
\hline $\mathrm{iu}$ & viu & viu & saw (3 sg) \\
\hline $\mathrm{eu}$ & meu & meu & mine \\
\hline$\varepsilon \mathrm{u}$ & veu & véu & veil \\
\hline $\mathrm{au}$ & mau & mau & bad \\
\hline$\tilde{\mathrm{e}} \mathrm{i}$ & š̃i & cem & hundred \\
\hline õi & e'nõif & anões & dwarves \\
\hline ũi & 'mũite & muita & much, many \\
\hline$\tilde{\mathrm{e} u}$ & 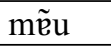 & $m \tilde{a} o$ & hand \\
\hline
\end{tabular}

(Cruz-Ferreira 1999: 127-128)

Portuguese also has oral and nasal triphthongs, formed of three vocalic elements at the same syllable, such as uai (Paraguai), uei (averiguei - I verified), uou (averiguou - he verified), uão (saguão - hall), and uõe (saguões - halls).

\section{EMPIRICAL STUDY}

At the Faculty of Arts of the University of Ljubljana, the Portuguese language and culture are taught as an elective subject, as well as a course (leitorado) of Portuguese language. The didactic textbook used in the first level is Português XXI, released by the Portuguese publishing house Lidel - Edições Técnicas (Tavares 2013a, 2013b, 2013c, 2013d, 2014). The students who attend the elective subject Portuguese 1 should reach the basic level A1 after 30 hours of work, and should master the level A1 after 60 hours of learning. The teaching is based on the method in Português XXI, which also includes the audio material recorded on the $\mathrm{CD}$, in addition to the textbook and workbook. Furthermore, every lesson has a few minutes of voice and visual contributions from the website of the Portuguese national television or radio broadcaster (https://www.rtp.pt/ noticias/videos, https://www.rtp.pt/play/p2851/palavras-de-bolso).

The textbook or Livro do aluno of Português XXI dedicates considerable attention to Portuguese phonetics. The auditory-voice exercises provide a lot of phonetic exercises in order to help students master the acquisition of new sounds, consisting particularly of those that the Slovene speakers perceive as specific Portuguese sounds, and as the difficult parts of the Portuguese phonetic system.

As such, in the first unit there are already pronunciation exercises for the sounds aiei-oi-ui-au-ao-eu-iu-ou and [n $\left.\kappa \int\right]$ (orthographical represented by $-\mathrm{nh}-\mathrm{lh}-\mathrm{ch}$ : pinha ['pine], pine cone; pilha ['pi Ke] ), battery; chato ['Jatu], flat); in the second unit the pronunciation of b, v, f (bato ['batu], I strike; vinha ['vina], vine; fato ['fatu], costume); and in the third the phonetic realization of $r$ in various positions in the word [в $\mathrm{c}$ (pira ['pire], pyre; rato ['вatu], mouse). Some lessons focus on the realisations of s and z (caço ['kasu] - I hunt; caso ['kazu] I marry), others on g and k (cacto ['kaktu] - cactus; gato ['gatu], cat $)^{4}$. Finally, the ninth unit is dedicated to nasal sounds in different environments - first

4 The exemples are from Cruz-Ferreira (1999: 126-127). 
those followed by the bilabial nasal [m] and nasalised by it (e.g.falam), then those which

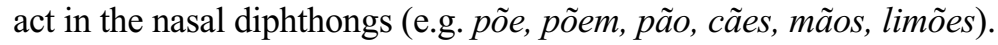

\subsection{Pilot Study}

In recent years, since the Faculty of Arts of the University of Ljubljana implemented the courses of Portuguese (leitorado) as well as Portuguese in the context of elective subjects, namely Portuguese 1 and 2, the authors of this paper have noticed that the pronunciation of nasal vowels, in monophthongs and diphthongs, seems to cause problems to Slovene speakers who are learning this language.

With the pilot study described below we focus on the production (and not perception) of nasal vowels. We try to answer the question as to whether the cause of the pronunciation problems that Slovene learners of European Portuguese have with the nasals is merely the absence of nasal vowels in the Slovene phonetic system, or whether there are some other factors involved.

Therefore, in the pilot study we focus on the test carried out by the student participants of the leitorado of Portuguese language and the elective subject Portuguese Language 1 at the Faculty of Arts. The experiment was conducted at the end of the winter semester, so the students who attended the one-semester course Portuguese 1 (leitorado) had already received 60 hours of exercises, and those who were enrolled in Portuguese 1 as an elective subject, carried out throughout the whole academic year (two semesters), had received 30 hours of exercises.

The pilot study was carried out with the help of twenty students aged 20 to 23, who also study another Romance language, i.e. Spanish, Italian or French, in their basic academic program. Both groups - the group P30 (Portuguese 1, 30 hours) with ten students and the group P60 (Portuguese 1 - leitorado, 60 hours) with the same - were surveyed.

The participants were asked to pronounce two sets of written words. In the first set (A)

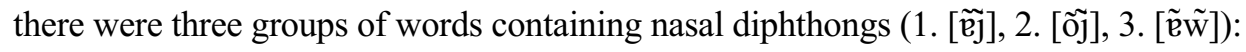

A.

1. $[\tilde{\mathrm{e} j}]-<\tilde{\mathrm{a} e}>,<\tilde{\mathrm{a} i}>,<\mathrm{em}>$

mãe (mother), cãibra (cramp), cem (hundred), sem (without), pães (loaves), cães (dogs), alemães (Germans);

2. $[\tilde{\mathrm{o} j}]-<\tilde{\mathrm{o} e}>$

põe (he puts), corações (hearts), lições (lessons), cantões (cantons), canções (songs), botões (bottons), oscilações (oscillations), contrações (contractions), conjugações (conjugations), relações (relations), distinções (distinctions), visões (visions);

3. $[\tilde{\mathfrak{e}} \tilde{\mathrm{w}}]<\tilde{\mathrm{a} o}>$ (stressed), $<\mathrm{am}>$ (unstressed)

pão (bread), irmãos (brothers), mulherão (big woman), Cazaquistão (Kazahstan, Kazakhstan), serão (they will be), andarão (they will go), estão (they are), são (they are), cantarão (they will sing), cantam (they sing), sintam (they shall feel), queriam (they have wanted, they wanted), amam (they love), amavam (they have loved, they loved), saibam (they shall know). 
The second set (B) consisted of selected words which represent the minimal pairs and contain nasal vowels:

B.

1. lá $[\mathrm{a}]-$ lã $[\tilde{\mathfrak{v}}] /$ (there - wool)

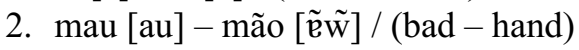

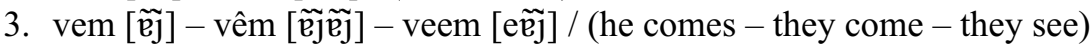

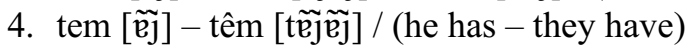

\subsection{The Results}

The results of the analysis of the recordings are as follows:

a. In the context of the set A1, in both groups of participants we noticed the correct nasal pronunciation of the nasals, particularly in the words mãe and alemães.

b. In the case of the words cem and sem from the set A1, we did not perceive the nasal pronunciation being produced by the vast majority of survey participants.

c. The set A2 presented problems with nasal pronunciation, especially in the case of longer and less frequent words that are still unknown to the students, e.g. oscilações, contrações, and conjugações.

d. In the set A3 we noticed a more correct, i.e. more nasal, pronunciation in the words with $[\tilde{\mathfrak{v}} \tilde{\mathrm{w}}]<$ ão> in the stressed syllable: pão, irmãos, mulherão, $\mathrm{Ca}$ zaquistão, serão, andarão, estão, são, and cantarão. Words like cantam, sintam, queriam, and so on, which are in particular verbal forms of the third person plural of different tenses in which the nasal vowel is unstressed, were pronounced by the survey participants as only slightly nasal or not at all, and stressed on the last syllable. The survey participants were wrong in putting the main stress on the last syllable. In the case of these verbal forms, the stress falls on the penultimate, and not on the last, nasal syllable.

e. The words in the sets B1 and B2 presented some problems of nasal pronunciation. In those cases where the nasal pronunciation was expected, we do not perceive it by the vast majority of survey participants.

f. Only rarely did the students pronounce the set of words in B3 (vem - vêm veem) correctly. The pronunciation of vem-vêm-veem that was observed from almost all the survey participants was a non-nasal [em], and not the correct nasal

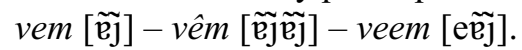

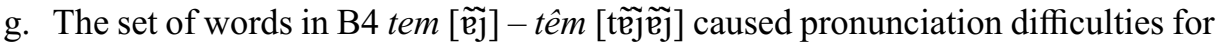
the majority of participants from both groups, P30 and P60. These words were

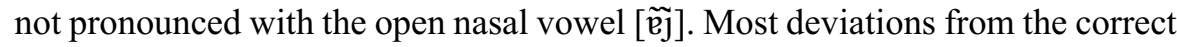
pronunciation were detected in distinguishing the two nasals that stand together

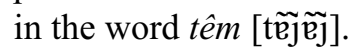

\subsection{Discussion}

The analysis of the pilot study offers some general observations. First, on the basis of the results that derive from the context of the set A1 in the pilot study, as described 
above, it should be emphasized that if the survey participants knew the meaning of the word, like mãe (mother), the nasal pronunciation was easier and more accurate than if the words were unknown to them, like cãibra (cramp). Within the domain of lexical availability, and in line with our expectations, those words with a higher lexical availability were better pronounced by the participants than the other items. It is obvious, moreover, that if words have greater lexical availability then this is due to the earlier and more frequent occurrence of these in the students' textbook; in our case, in the elective course of Portuguese 1 and the course of the Portuguese language (leitorado). Furthermore, if the written word was shorter, like pão (bread), then a stricter nasal pronunciation was achieved than in the case of longer and less frequent words in the set A2, which were mostly still unknown to the participants, like oscilações, (oscillations). Nevertheless, in the case of the short words cem and sem, also in the set A1, we did not perceive the nasal pronunciation being produced by the vast majority of the participants.

Considering the issue of orthography as well as the results of the pilot study, the graphic accent in the nasal diphthong ão, as in pão (bread), seems decisive for achieving the nasal pronunciation in comparison with the terminal nasal ending -am, as in cantam (they sing). This was observed in the context of the set A3, where a more correct, i.e. more nasal pronunciation, was noticed in the words with $[\tilde{\mathfrak{e}} \tilde{\mathrm{w}}]<\mathrm{a} 0>$ at the stressed syllable. However, and also in the set A3, words like cantam, sintam, queriam, etc., which are particular verbal forms of the third person plural of different tenses, and in which the nasal vowel is unstressed, were pronounced by the participants as only slightly or not at all nasal, and stressed, as was already noted above. The survey participants were thus not successful in identifying the main stress in the word. The stress, in the case of these verbal forms, falls on the penultimate, rather than the last, nasal syllable. These results lead to the conclusion that the graphic accent in the nasal diphthong ão helps the students to identify the nasal pronunciation, while the orthographic representation -am, although requesting the same pronunciation, leads the Slovene speaker to the wrong, non-nasal pronunciation.

Still, within the domain of orthography and with respect to the pronunciation of the words from the set B3, it could be claimed that the students, when pronouncing the selected words of B3, are misled by the orthographic representations of the words as vem

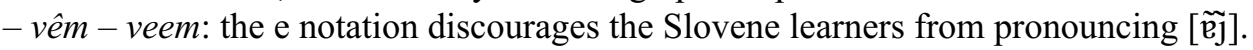

The words from the sets B1 and B2 presented problems with regard to nasalisation, and those which should have nasal pronunciation were pronounced without it. There-

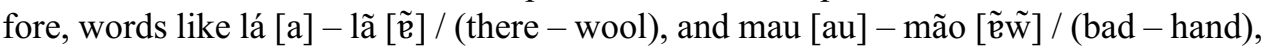
lost a phonologically distinctive value, due to the non-nasal pronunciations of the participants. It thus seems that the graphic sign in both minimal pairs did not interfere with the participants' pronunciation in this study.

The set B3, as already mentioned above, was a problem for both groups, P30 and P60. In rare cases the students pronounced the words vem - vêm - veem (he comes they come - they see) correctly. In line with these results, it could be concluded that the difficulty is two-fold: the openness of the vowels and the nasal pronunciation of the 
nasal vowels. The pronunciation of vem - vêm-veem, which was observed with almost all participants, was with e and non-nasal [em], and not with the correct a and nasal vem

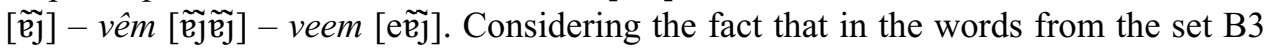
vem - vêm-veem the orthographic representation is e and not a, we believe that this sign may cause the Slovene speakers at this level of learning Portuguese to avoid the nasal pronunciation $[\tilde{\mathrm{e} j}]$.

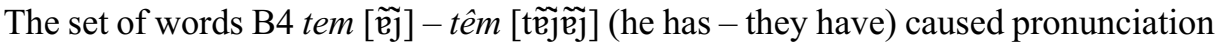
difficulties for the majority of participants from both P30 and P60, and these were not pronounced with an open nasal vowel. Most deviations from the correct pronunciation were detected in distinguishing the two nasals that stand together in the word têm

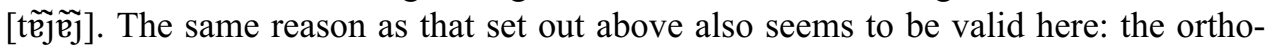
graphic representation of the words tem and têm probably caused the Slovene speakers to make the wrong pronunciation.

\section{CONCLUSION}

To the best of our knowledge, the present paper represents one of the few studies in the academic literature on Slovene (L1)/Portuguese (L2) pairs in the domains of phonetics and phonology.

The main purpose of this paper was to shed a new light on a specific situation of Slovene students of Portuguese as a foreign language (L2), considering the fact that there are some sounds in Portuguese that have no near equivalents in Slovene. In order to achieve this goal, we described the main features of the sound systems of European Portuguese (L2) and Slovene (L1), in particular from the points of view of place and manner of articulation, while also focusing on the pronunciation of nasal vowels and diphthongs in European Portuguese. Consequently, we tried to realize the key aim of this paper, which was to identify the pronunciation of nasal vowels and diphthongs in European Portuguese as a problem area of Portuguese pronunciation for native Slovene speakers. Furthermore, we carried out - with the help of student participants from the elective subject Portuguese 1 and the course of Portuguese Language 1 (leitorado) at the Faculty of Arts of the University of Ljubljana - a pilot study focused on the production of nasal vowels.

A number of interesting questions arose during the study described in the paper, and we have aimed to address them: e.g. we mentioned the fact that in teaching Portuguese more attention should be paid to the pronunciation of nasal sounds in words such as tem - têm, where orthographic presentation does not point to the nasal pronunciation (in this case $[\tilde{\mathrm{E}}]]-[\hat{\mathrm{E} j} \mathrm{j} \tilde{\mathrm{B}}]]$ ), especially since the incorrect pronunciation causes the loss of a distinctive phonological value.

There are certain other issues that we would like to point out. It should be stressed that although we expected that the students who had taken more hours of Portuguese (the P60 group) would be more likely to pronounce the nasal sounds better, we did not observe better pronunciation in this group when we compared to that of the P30 group. It seems that the thirty additional study hours taken by the P60 group did not contribute significantly to a more accurate pronunciation of nasal sounds. We may 
thus claim that more attention should be paid to Portuguese phonetics, as more time and much more practice is required in teaching/learning this language for native Slovene speakers.

Additionally, experience of teaching the elective subject Portuguese 1 and the practical course of Portuguese language 1 (leitorado) shows that when students repeat material that they listen to there are fewer problems in the pronunciation of the nasal vowels than when they are asked to read written material in Portuguese. Furthermore, as one of the general findings based on the results of the pilot study, it should be emphasized that the errors in the pronunciation of the nasal vowels are strongly associated with the lexical availability of the word(s), the level of acquired knowledge of Portuguese, and the interference of Portuguese orthography.

The results of this pilot study open up some avenues for further research. For example, future studies should analyse the differences in the acquisition of nasal vowels by Slovene students of different Romance languages, especially French, due to the use of nasal pronunciation in this language, in comparison with Italian or Spanish.

As an answer to the key question as to whether the cause of the problems in the pronunciation of nasal vowels and diphthongs in European Portuguese by Slovene learners is merely the absence of nasal vowels in the Slovene phonetic system, or whether there are other factors involved, the authors of this paper believe that the results of this study show that the problem with the pronunciation of Portuguese nasals is related to the absence of nasal vowels in the Slovene phonetic system, but is also connected with the fact that the Portuguese sound system requires more attention, time and work in the classroom, which all remain a challenge.

\section{References}

AZEVEDO, Milton. M. (1981) Contrastive Phonology of Portuguese and English. Washington D.C: Georgetown University Press.

CRUZ-FERREIRA, Madalena (1999) "Portuguese (European)." In: Handbook of the International Phonetic Association. A Guide to the Use of the International Phonetic Alphabet. Cambridge: Cambridge University Press, 126-130.

CUNHA, Celso/Lindley CINTRA (1984) Nova Gramática do Português Contemporâneo. Lisboa: Edições João Sá da Costa.

ESPADA, Francisco (2017) Manual de Fonética - Exercícios e Explicações. Lisboa: LIDEL - Edições Técnicas.

MARKIČ, Jasmina (2008) "A Contrastive Approach in Teaching European Spanish and European Portuguese Pronunciation to Slovene Students." In: Schurt Rauber, Andréia (ed.), New Sounds 2007: Proceedings of the Fifth International Symposium on the Acquisition of Second Language Speech, November 25 to 28, 2007, Florianópolis, Santa Catarina, Brasil, 317-323. http://www.nupffale.ufsc.br/newsounds/Papers/29.Markic_Jasmina.pdf

MATEUS, Maria Helena Mira/Isabel FALÉ/Maria João FEITAS (2005) Fonética e Fonologia do Português. Lisboa: Universidade Aberta. 
MATEUS, Maria Helena Mira/Ana Maria BRITO/Inês DUARTE/Isabel Hub FARIA (2006) Gramática da Língua Portuguesa. Lisboa: Caminho.

ROTHE-NEVES, Rui/Camila M. REIS (2012) "Uma bibliografia da nasalidade vocálica no português." Letras de Hoje 47/3, 299-305.

ŠUŠTARŠIČ, Rastislav/Smiljana KOMAR/Bojan PETEK (1999) "Slovene." In: Handbook of the International Phonetic Association. A Guide to the Use of the International Phonetic Alphabet. Cambridge: Cambridge University Press, 135-139. TAVARES, Ana (2013a) Português XXI. Livro do aluno. Nivel A1. Lisboa: Lidel TAVARES, Ana (2013b) Português XXI. Caderno de exercicios. Nivel A1. Lisboa: Lidel TAVARES, Ana (2013c) Português XXI. Livro do aluno. Nivel A2. Lisboa: Lidel TAVARES, Ana (2013d) Português XXI. Caderno de exercicios. Nível A2. Lisboa: Lidel TAVARES, Ana (2014) Português XXI. Livro do professor. Nivel A2. Lisboa: Lidel TOPORIŠIČ, Jože (1984) Slovenska slovnica. Maribor: Založba Obzorja.

\section{Reference Works}

TYPE IPA PHONETIC SYMBOLS. http://ipa.typeit.org

A PRONÚNCIA DO PORTUGUÊS EUROPEU. http://cvc.instituto-camoes.pt/cpp/ acessibilidade/capitulo1_1.html

\section{Abstract \\ NASAL VOWELS AND DIPHTHONGS IN EUROPEAN PORTUGUESE: A PROBLEM FOR SLOVENE SPEAKERS}

Portuguese, a Romance language, and Slovene, a Slavic language, are distant in the geographical, historical, cultural and linguistic senses. There are not many contrastive studies of these two languages, and even fewer in the phonetic-phonological field. The present work is limited to the study of standard European Portuguese (PE) and aims to address one of the major problems in teaching Portuguese phonetics to Slovene speakers: the correct production of Portuguese nasal vowels.

After a contrastive presentation of the vowel systems of both languages, the study is limited to Portuguese nasal vowels and diphthongs, which do not exist in Slovene. The analysis of Portuguese vowels is fundamentally related to the position of the accent: stressed vowels and pretonic, postonic or final vowels. The nasal vowels are presented in smaller numbers than the oral ones and do not occur in postonic syllables, except in some diphthongs. This work presents the analysis of a practical survey carried out in Portuguese classes for Slovene students of level A at the University of Ljubljana and is focused on the production of nasal vowels by Slovene speakers. The objective is to highlight the errors produced, to look for the causes in order to improve the teaching of this aspect of the phonetics and phonology of the European Portuguese.

Keywords: contrastive analysis, European Portuguese, Standard Slovene, nasal vowels, nasal diphthongs 


\section{Povzetek \\ NOSNI SAMOGLASNIKI IN DVOGLASNIKI V EVROPSKI PORTUGALŠČINI KOT PROBLEM ZA SLOVENSKE GOVORCE}

Portugalščina, ki je romanski, in slovenščina, ki je slovanski jezik, sta precej oddaljena jezika, tako $\mathrm{v}$ geografskem, zgodovinskem in kulturnem smislu kot tudi jezikovno. Doslej na področju protistavnih študij teh dveh jezikov ni bilo opravljenih veliko raziskav, zlasti ne na področju fonetike in fonologije. Pričujoči prispevek se ukvarja s preučevanjem standardne evropske portugalščine (PE) in je namenjen osvetlitvi in iskanju rešitve za morda enega glavnih problemov pri poučevanju portugalske fonetike slovenskih govorcev, portugalskim nosnim samoglasnikom.

Po protistavni predstavitvi samoglasniških sistemov $\mathrm{v}$ obeh jezikih se prispevek osredotoča na portugalske nosne samoglasnike in dvoglasnike, ki v slovenskem jeziku ne obstajajo. Analiza portugalskih samoglasnikov je zlasti povezana s položajem naglasa (poudarjeni in nepoudarjeni samoglasniki v poziciji pred naglasom ali po njem, končni samoglasniki). Nosni samoglasniki so navzoči v manjšem številu kot nenosni in se ne pojavljajo v zlogih, ki se nahajajo za naglasom, razen $\mathrm{v}$ nekaterih dvoglasnikih. Pričujoči prispevek predstavlja analizo, ki izhaja iz praktičnega preizkusa, opravljenega s slovenskimi študenti izbirnega predmeta Portugalščina 1 na ravni A1 na Filozofski fakulteti Univerze $\mathrm{v}$ Ljubljani, in se osredotoča na produkcijo nosnih samoglasnikov s strani slovenskih govorcev. Namen te raziskave je opozoriti na napake, ki se pojavljajo pri izgovarjanju nosnih samoglasnikov, poiskati vzroke za napake in tako najti načine, ki bi omogočali boljše poučevanje tega vidika fonetike in fonologije evropske portugalščine.

Ključne besede: protistavna analiza, evropska portugalščina, knjižna slovenščina, nosni samoglasniki, nosni dvoglasniki 